Krzysztof FORMICKI ${ }^{1}$, Mieczysław KOWALEWSKI ${ }^{2}$

Andrzej SOBOCIŃSKI ${ }^{1}$, Aleksander WINNICKI ${ }^{1}$

Embryology

\title{
SPERM QUALITY OF GRAYLING (THYMALLUS THYMALLUS L.) UNDER NATURAL CONDITIONS AND IN PONDS
}

\section{JAKOŚĆ NASIENIA LIPIENIA (THYMALLUS THYMALLUS L.) ŻY JĄ CEGOW WARUNKACH NATURALNYCH I W STAWACH}

\author{
1 Department of Anatomy and Embryology of Fish, University of \\ Agriculture, Szczecin \\ ${ }^{2}$ Polish Anglers Association Station at Lopuszna
}

Spermatozoa quality of two grayling. (Thymallus thymallus L.) populations: free - living and bred in ponds, was compared. The percentage of spermatozoa activated upon contact with water, time of progressive movement (turbulent and smooth phase), time of oscillatory movement and the spermatocrit were determined. Males living in a river, as compared with those rared in a pond, displayed a significantly higher percentage of activated spermatozoa, whereas both populations did not significantly differ in spermatozoa motility and spermatocrit.

\section{INTRODUCTION}

European grayling (Thymallus thymallus L.) is one of the most beautiful freshwater fish. It lives in submontane rivers with fast current and in some highly oligotrophic lakes. This species occurs in almost the whole of Europe, except for Southern France and Spain [Nikolski, 1970; Witkowski et al., 1984].

Since a long time grayling has been particularly highly rated on account of the excellent organoleptic value of its meat and on sport reasons. In this respect it 
exceeds many species, being inferior to only few freshwater fish, e.g. trout; its fat content is distinctly lower than that of salmon, trouts, whitefish or vendace [Lusk, 1969; Lusk and Skacel, 1978; Witkowski et al., 1964]. This had led in recent years to greatly increased interest in grayling and to initiation of the production and breeding of stock material.

As a rule, in grayling rearing in closed water bodies use is made of spawners obtained from open waters during their spawning migration. Moreover, breeding of spawners in ponds has also been attempted. The quality of fish sexual products, and in particular the percentage of the activated spermatozoa and their motility, is of very. great importance for fertilization and thus for the success of rearing. Therefore, in the present studies we resolved to compare the quality of sperm of males derived from two populations: free-living in a river and bred in a pond, as related to spawner age. The scarcity of literature concerning the motility of grayling spermatozoa [Roth et al., 1950] was an additional ground for undertaking these studies.

\section{METHODS}

The material consisted of sperm of grayling (Thymallus thymallus L.), obtained from individuals caught in early spring, and derived from two population: one living in the Dunajec River (32 males) and another one bred at the Stocking Centre of the State Fishery Works in Łopuszna near Nowy Targ (38 males), in the years 1989 and 1990. Sperm of each male was examined twice, immediately after its collection (in total, 140 measurements); every time the number of spermatozoa activated upon contact with water, the time of the progressive and oscillatory (pendular) movement, and the spermatocrit were determined. In the case of the progressive movement, two phase: turbulent and smooth, were singled out [Formicki et al., 1989; Formicki et al., 1990]. Measurements were taken under an optical mikroscope (200 x), exact to $0.5 \mathrm{sec}$ [Tomasik, 1973]. For each male the spermatocrit (relative volume of the spermatozoa in a sperm sample) was determined in triplicate using a hematocrit centrifuge according to Winnicki and Tomasik [1976] (5000 rpm, centrifugation time $5 \mathrm{~min}$ ).

The same water as that in which the males were kept was used in the tests $\left(9^{\circ} \mathrm{C}\right)$. Fish were divided into age groups $(3,4,5,6$ years).

For statistical treatment multifactor analysis of variance (ANOVA) was applied; statistically homogenous groups were singled out by Duncan's test [Elandt, 1964]. 
[\%]

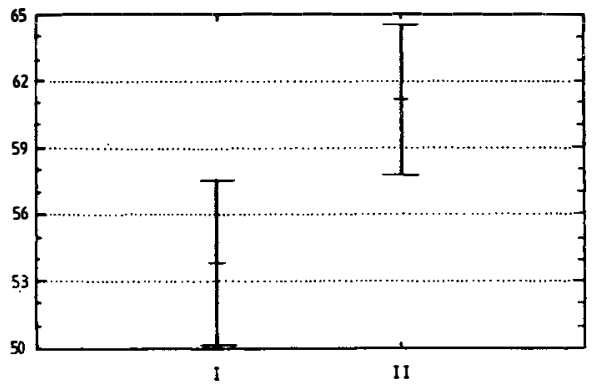

[\%]

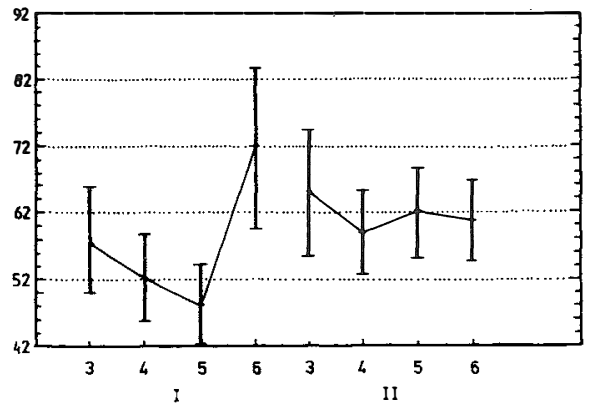

Fig. 1. Percentage of activated spermatozoa in reared and free-living grayling (Thymallus thymallus L.), globally and in age groups
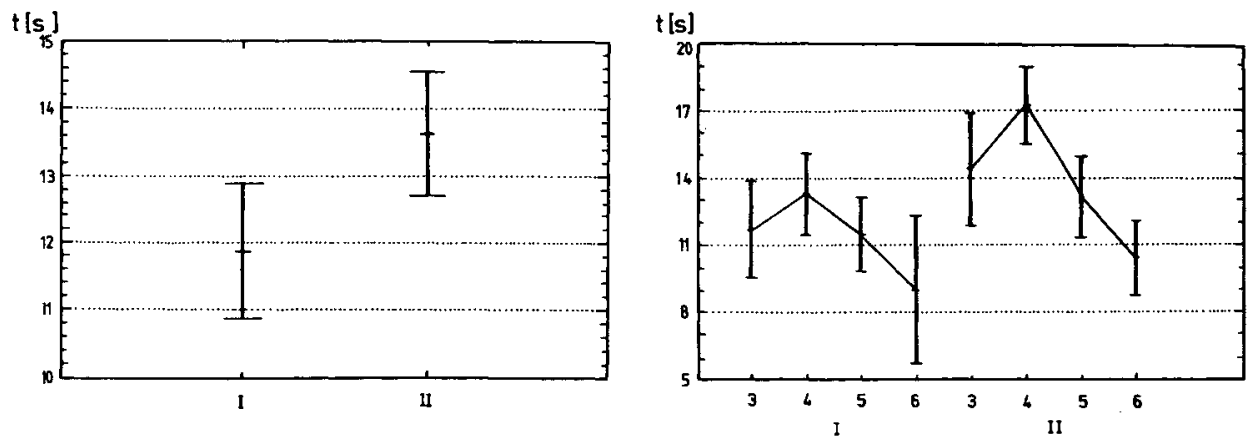

Fig. 2. Time of spermatozoa movement (turbulent phase) in reared and free-living grayling (Thymallus thymallus L.), globally and in age groups
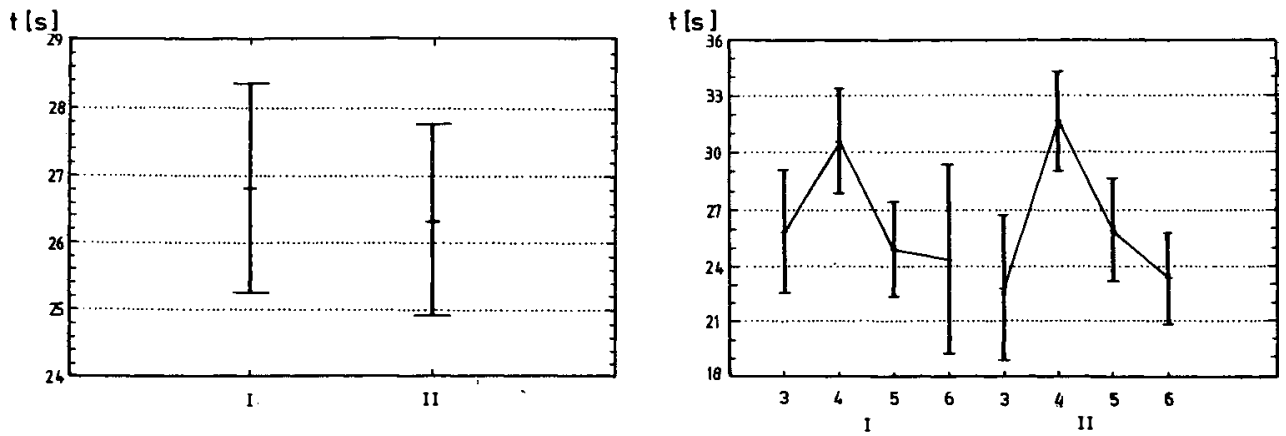

Fig. 3. Time of spermatozoa progressive movement in reared and free-living grayling

(Thymallus thymallus L.), globally and in age groups 

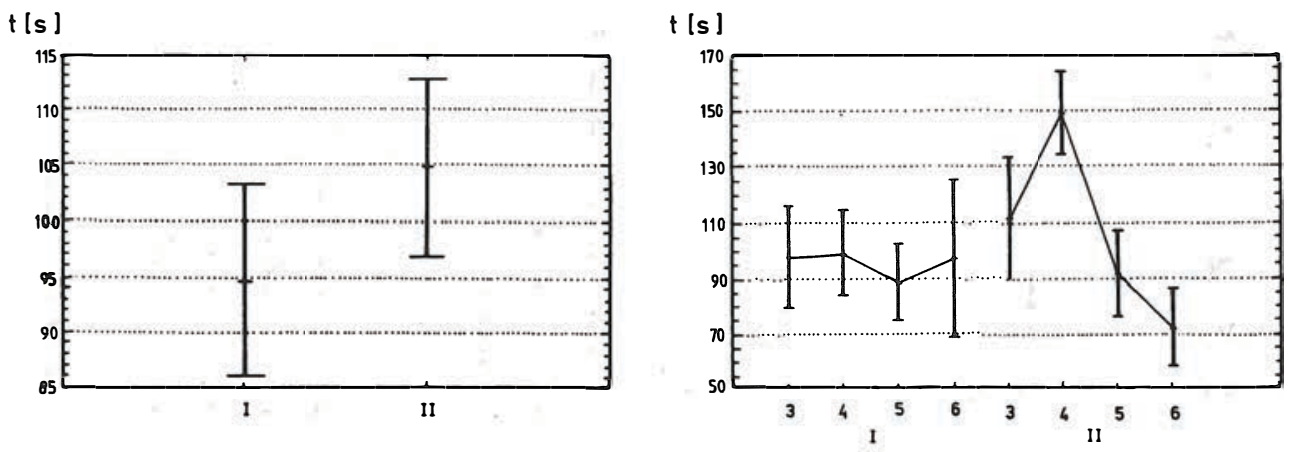

Fig. 4. Total time of spermatozoa movement in reared and free-living grayling (Thymallus thymallus L.), globally and in age groups

[\%]

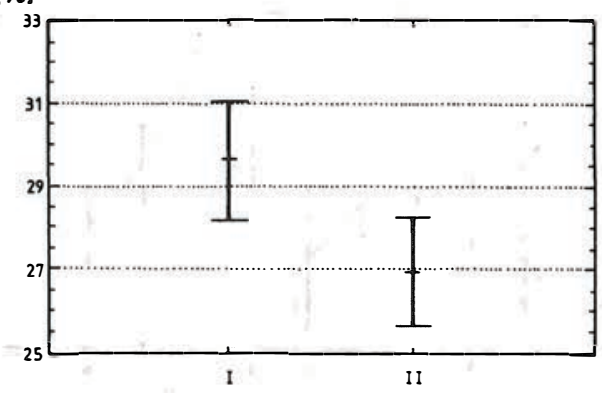

[\%]

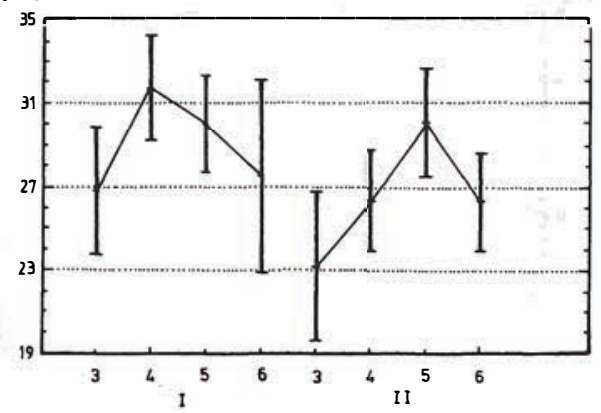

Fig. 5. The spermatocrit of the spermatozoa of reared and free-living grayling (Thymallus thymallus L.), globally and in age groups

\section{RESULTS}

The percentages of activated spermatozoa in the free-living and reared grayling population are presented in Fig. 1. The percentage is significantly higher for the free-living than for the reared males, in the case of the latter this percentage varies between age groups, whereas in the free-living males it remains on an approximately similar level.

The turbulent phase of the progressive movement of the spermatozoa lasts somewhat longer in the case of sperm of free-living males (Fig. 2). The time of the progressive movement is fairly similar in both populations; it is longest for 4-year old individuals (Fig. 3). It is noteworthy that the free-living males, in contrast to the reared ones, display a progressing decrease in the spermatozoa motility time (upon comparison of the total movement), beginning from the 4th year of age (Fig. 4). 
The 3-6 years old reared males are characterized by relatively high stability of the spermatozoa motility. In free-living males this motility (particularly the turbulent phase and progressive movement) attains a maximum in the 4th year of age, whereupon it drops fairly evidently.

For the reared and free-living males the spermatocrit amounts to 29.6 and $26.9 \%$, respectively; the difference is insignificant (Fig. 5).

\section{DISCUSSION}

Grayling is an open-water species. It occurs in stocks in deep or shallow waters, and its mode of life is rather stationary. Only in spring it migrates to spawning grounds, usually to a distance of $30-40 \mathrm{~km}$. The growth rate and gain in body weight depend on the living conditions. The wider and purer the waters, the better the development of grayling, in contrast to the reared population living within a limited area and deprived of natural liberty.

In this connection it was of interest to elucidate whether living condition differing from the natural ones may exert a significant effect on the value of the sexual products, in this case on the quality of sperm and on its physiological properties.

The present results univocally indicate that the living conditions of males only slightly influence the quality of their sperm. This is fully justifiable, since it could hardly be expected that the course of the fundamental intimate reproduction - ensuring biological processes formed by nature would significantly change in the course of one generation, the more so that exactly in the case of reproduction mechanism there applies a specific "conservatism" allowing for species preservation.

The observed, very interesting, sometimes even significant differences between males from both populations in the number of the spermatozoa activated after spawning or in the time of the various motility phases should rather be attributed to dissimilarities in "spawning preparedness" which is more differentiated in the "migrating" males and more stable in the reared ones. This assumption is supported by e.g. the lower percentage of activated spermatozoa in the reared than in the "migrating" individuals, this pointing to greater "spawning preparedness" of the later. This assumption is confirmed by the lower spermatocrit index found for the free-living males. 
The occurence of relatively high quality indices of sperm in 4 years old males is justifiable, since in general the course of the sexual maturity period in fish is characterized by this kind of phenomena which result from biological stability of the reproduction cycles and physiological mechanism regulating the reproduction being of the greatess importance in the life of species.

The above considerations and the present results indicate that the succesful large-scale attempts at rearing a basic grayling population are of practical importance. They allow for the production of stocking material and thus for assisting the original grayling populations living under natural conditions. This is increasingly more important since the water bodies inhabited by this species are subject to progressively potentiated degradation which deteriorates the conditions of its reproduction.

\author{
REFERENCES
}

Elandt Ro, 1964: Statystyka matematyczna $w$ zastosowaniu do doświadczalnictwa rolniczego, [Mathematical statistics and its application to experiments in agriculture]. PWN, Warszawa. (in Polish). Formicki K., M. Kowalewski, A. Sobociñski, L. Tomasik, A. Winnicki, 1989: Motility of Danube salmon (Hucho hucho L.) spermatozoa after activation. - Acta Ichth. Pisc., 19, 2: 29-35.

Formicki K., A. Sobocinski, A. Winnicki, 1990: Motility of spermatozoa of Danube salmon (Hucho hucho L.). exposed to magnetic field prior to activation. - Pol. Arch. Hydrobiol., 37, 3: 435-443.

Lusk S., 1969: The utility volume of the brown trout, Salmo trutta m. fario L., and the grayling, Thymallus thymallus L., Zool. Listy, 18: 81-92.

Lusk S., L. Skåcel, 1978: Lipan̆, Priroda, Bratislava.

Nikolski G.V., 1970: Ichtiologia szczegółowa. [Ichthyology]. PWRiL. Warszawa. (in Polish).

Roth H., F. Medem, A. Rötheli, 1950: Biologischer Nachweis von Befruchtungsstoffen bei Hecht und Asche. - Schweiz. Ztschr. f. Hydrol., 12: 68-78.

Tomasik L., 1973: Specific and individual differences in motility between salmonid spermatozoa. - Acta Ichth. Pisc., 3, 1: 11-17.

Winnicki A., L. Tomasik, 1976: "Spermatocrit" as a method for biological evaluation of fish sperm. Acta Ichth. Pisc., 6, 2: 3-8.

Witkowski A., M. Kowalewski, B. Kokurewicz, 1984: Lipień [Grayling]. PWRiL, Warszawa. (in Polish). 
Krzysztof FORMICKI, Mieczysław KOWALEWSKI, Andrzej SOBOCIŃSKI, Aleksander WINNICKI

\author{
JAKOŚĆ NASILENIA LIPIENIA (THYMALLUS THYMALLUS L.) \\ ŻYJĄCEGO W WARUNKACH NATURALNYCH I W STAWACH
}

\title{
STRESZCZENIE
}

Porównano jakość plemników lipienia (Thymallus thymallus L.) populacji wolno żyjącej i hodowanej w stawach. Badano odsetek aktywujących się plemników po zetknięciu z wodą, czas ruchu postępowego (faza burzliwa i spokojna), czas ruchu wahadłowego oraz spermatokryt. Stwierdzono, iż u samców żyjących w rzece odsetek aktywujących się plemników jest istotnie wyższy, ale ruchliwošć plemników i spermatokryt u obu populacji nie wykazują istotnych różnic.

Author's address:

Prof. dr hab. Krzysztof Formicki, mgr inż. Andrzej Sobociński, prof. dr hab. Aleksander Winnicki

Zakład Anatomii i Embriologii Ryb

Akademia Rolnicza

ul. K. Królewicza 4

71-550 Szczecin

Polska (Poland)

Mgr inż. Mieczysław Kowalewski

Ośrodek Zarybieniowy Polskiego Związku Wędkarskiego

34-432 Łopuszna koło Nowego Targu

Polska (Poland) 